\title{
The Analysis of Factors Affecting Dividend Payout Ratio in Manufacturing Companies Listed in Indonesian Stock Exchange
}

\author{
Annur Fitri Hayati ${ }^{1}$, Gusti Astuti ${ }^{2}$, Khairi Murdy ${ }^{3}$ \\ ${ }^{1}$ Dept. of Economics Education, Faculty of Economics, Universitas Negeri Padang, Padang, Indonesia \\ $\triangle($ e-mail) annurfitrihayati@gmail.com \\ 2STKIP Aisyah Pekanbaru, Pekanbaru, Indonesia \\ $\triangle($ e-mail) g_astuti@yahoo.com \\ ${ }^{3}$ STKIP Aisyah Pekanbaru, Pekanbaru, Indonesia \\ $\triangle$ (e-mail) khairimurdy02@gmail.com
}

\begin{abstract}
This study aims to conduct a fundamental study of factors affecting the dividend policy of manufacturing companies listed in the Stock Exchange. The sample of this study was 21 manufacturing companies listed in the Indonesian Stock Exchange (IDX). The type of data used was secondary data in the form of financial statements contained in the directory of Indonesian Stock Exchange in the book Indonesian Capital Market Directory (ICMD). The statistical method used to test the research hypotheses was multiple regression with six independent variables, namely, debt to total assets, cash ratio, firm size, return on assets, and growth, and dependent variable of dividend payout ratio. It can be concluded that debt to total assets (DTA), firm size, and return on assests (ROA) have influence on dividend payout ratio at manufacturing companies listed in Indonesian Stock Exchange.
\end{abstract}

Keywords: debt to total assets, cash ratio, return on assets, growth, and dividend payout ratio

\section{Introduction}

In line with the growth of a company to advance business and economics in the digital era, the company needs funds to expand, improve capital structure, launch new products or for other purposes. Funding sources can come from within the company as well as from outside the company. The capital market is a better source of funding than the banking sector. The banking sector disbursed funds in the form of credits while the capital markets enabled the collection of funds in the form of equity thus avoiding too much debt reliance. The capital market is also a funding alternative with a lower cost, this is because the parties who need funds with the parties who distribute the funds directly related. While the banking sector needs an intermediary fee between parties who need funds with the excess funds. The funds raised will be used for investment activities which will be expected to generate dividends and capital gains.

Saxena (1999 in Chasanah, 2008) argues that the issue of dividend is important for several reasons: First, firms use dividend as a way of showing to outsiders or potential investors in relation to the stability and future growth prospects of the company. Second, dividend plays an important role in the capital structure of the company.

The amount of dividend paid is also dependent on the policies of each company, so management considerations are needed. The dividend policy is a policy that involves two interested parties and the two are at odds with each other, namely the interests of shareholders with their dividend and the interests of the company with its retained earnings (Arilaha, 2013). Brigham and Houston (Brigham \& Houston, 2010)state that the change in the amount of dividends distributed has two consequences, that is, if all profits are paid as dividends then the interest of the reserves will be ignored, whereas the retained earnings of all shareholders' interests will be ignored. In the future, the shareholders will prefer dividends now rather than the high return of capital gains. For the group of investors who choose the return of the estimated dividend, the amount of dividend received is very important to 
decide which shares to choose. To maintain these two interests, the manager can take the optimal policy.

According to Brigham and Huston (2001 in Praswati et al., 2016), the optimal policy is a dividend policy that creates a balance between current dividends and future growth that will maximize stock prices. That means the policy taken should be able to meet the needs of funds, while the investor gets what is desired, so that investors do not transfer other investments keperusahaan. The amount of revenue per share distributed in the form of dividends is shown in the dividend payout ratio. Based on the empirical data on the dividend payout ratio, several firms experienced fluctuations, from 2011 to 2014 there was an increase and decrease in the dividend payout ratio in the manufacturing companies. But what is interesting here is that the company IMAS recorded no net profit in 2014 but management decided to keep distributing dividend.

This is incompatible with some theories. Among them are Bambang (2008) who stated that the dividend policy stems from how the management treatment of the profits derived by the company which is generally part of the net after taxpus (EAT) is distributed to investors in the form of dividends and partly reinvested to the company in the form retained earning. IMAS company management chooses to keep distributing dividend to investors even though the company has no net income. This becomes one of the empirical evidence that the company's ability to generate profit (profitability) is not always a consideration in the decision to distribute dividend. Therefore, there is a need for further research on factors affecting dividend payment ratio (DPR). Setyawan (in Handayani, 2010) classifies various factors affecting dividend-sharing policy into 2 factors, namely: (1) Internal factors are factors from within the company that affect the dividend-sharing policy, such as corporate liquidity, profit rate, and ability to borrow fund. (2) External factors, an influence that comes from outside the company, for example: tax or capital gains, access to capital markets and regulations that apply. The results of previous research so far also provide many contradictory views, where there are research gaps for some variables that affect the House. In this research, there are several factors that influence the determination of dividend payout ratio, among others are Brigham and Houston (2010) debt to total asset, cash ratio, size, return on asset, and growth. The results of previous studies that provide contradictory views as shown in the Table 1.

Table 1 The summary of research findings on factors influencing dividend payout ratio

\begin{tabular}{lccccc}
\hline Researcher & $\begin{array}{c}\text { Debt to } \\
\text { Total Assets }\end{array}$ & Cash Ratio & $\begin{array}{c}\text { Return on } \\
\text { Asset }\end{array}$ & Firm Size & Growth \\
\hline $\begin{array}{l}\text { Chasanah } \\
(2008)\end{array}$ & No effect & Take effect & Take effect & No effect & No effect \\
\hline $\begin{array}{l}\text { Puspita } \\
(2009)\end{array}$ & No effect & Take effect & Take effect & Take effect & No effect \\
\hline $\begin{array}{l}\text { Handayani } \\
(2010)\end{array}$ & $\begin{array}{c}\text { Not a } \\
\text { research } \\
\text { variabel }\end{array}$ & $\begin{array}{c}\text { Not a } \\
\text { research } \\
\text { variabel }\end{array}$ & Take effect & Take effect & $\begin{array}{c}\text { Not a } \\
\text { research } \\
\text { variabel }\end{array}$ \\
\hline $\begin{array}{l}\text { Basuki } \\
(2012)\end{array}$ & No effect & No effect & No effect & $\begin{array}{c}\text { Not a } \\
\text { research } \\
\text { variabel }\end{array}$ & $\begin{array}{c}\text { Not a } \\
\text { research } \\
\text { variabel }\end{array}$ \\
\hline $\begin{array}{l}\text { Hidayat } \\
(2015)\end{array}$ & $\begin{array}{c}\text { Not a } \\
\text { research } \\
\text { variabel }\end{array}$ & No effect & Not a research & $\begin{array}{c}\text { Not a } \\
\text { research } \\
\text { variabel }\end{array}$ & $\begin{array}{c}\text { Not a } \\
\text { research } \\
\text { variabel }\end{array}$ \\
\hline $\begin{array}{l}\text { Muktisari } \\
\text { (2015) }\end{array}$ & $\begin{array}{c}\text { Not a } \\
\text { research } \\
\text { variabel }\end{array}$ & $\begin{array}{c}\text { Not a } \\
\text { research } \\
\text { variabel }\end{array}$ & No effect & $\begin{array}{c}\text { Not a } \\
\text { research } \\
\text { variabel }\end{array}$ & $\begin{array}{c}\text { Not a } \\
\text { research } \\
\text { variabel }\end{array}$ \\
\hline
\end{tabular}


This study aims to conduct a fundamental study of the factors that affect the dividend policy of the company, especially manufacturing companies listed on the Stock Exchange. Based on some previous research results that have been described, these variables have not given consistent results that need to be tested again. Based on the description that has been described above, the authors formulate the problem as follows.

Do debt to total assets, cash ratio, firm size, return on assets, and growth significantly influence both simultaneously and partially to dividend payout ratio at manufacturing companies listed on the Indonesian Stock Exchange?

This study formulated hypotheses as follows.

$\mathrm{H}_{1}$ debt to total assets has a significant effect on dividend payout ratio

$\mathrm{H}_{2}$ cash ratio has a significant effect on dividend payout ratio

$\mathrm{H}_{3}$ firm size has a significant effect on dividend payout ratio

$\mathrm{H}_{4}$ return on assets has a significant effect on dividend payout ratio

$\mathrm{H}_{5}$ growth has a significant effect on dividend payout ratio

It is expected that this research contributes to the stream of research examining teh influence of debt to total asset, cash ratio, firm size, return on asset, and growth on dividend payout rasio. As such, it can later assist company in improving its image and help investor take decision in making decision plant his shares.

\section{Methods}

The observed population in thi sstudy was all manufacturing companies listed in the Indonesian Stock Exchange (IDX) and have active shares for four consecutive years i.e. from 2011 to 2014 which resulted with 149 companies. The sampling technique used was purposive sampling method, the sample was selected by using certain considerations that are adjusted to the research objectives or research problems developed by Ferdinand (2006 as cited in Muktisari, 2015). The criteria used were as follows:

1. The company under study is a manufacturing company listed on the BEI from 2011 and remains listed on the Stock Exchange until 2014. This was intended for continuous data.

2. Manufacturing companies listed on the BEI and have issued complete annual financial statements from 2011 to 2014 . There are 130 companies. It was intended for the completeness of data used according to the research model.

3. Companies that pay dividends for 4 (four) consecutive years from 2011, 2012, 2013 and 2014. Companies that meet the criteria are 21 companies. This was because the focus of this research ison factors that influence dividend payout ratio (DPR).

This study used secondary data. The data used in this study were financial statements and online annual publications reported to Indonesian Stock Exchange (IDX), Cash Dividend Report from ebursa.com online site, and the capital market information center (PIPM). This study used quantitative analysis technique, namely, multiple regression method. The formula for the regression test was formulated as follows:

$$
Y=a+b_{1} X_{1}+b_{2} X_{2}+b_{3} X_{3}+b_{4} X_{4}+b_{5} X_{5}+e
$$

where

$\mathrm{Y} \quad$ : Dividend Payout Ratio

A : Constanta

B $(1,2,3,4,5) \quad$ : Coefisien Regresion

$X_{1} \quad$ : Debt to Total Assets

$\mathrm{X}_{2} \quad$ : Cash Ratio

$X_{3} \quad:$ Return on Assets

$X_{4} \quad:$ Firm Size

$X_{5} \quad:$ Growth 


\section{Results and Discussion}

Before hypotheses test was conducted, the data was checked for its adherence to the regression assumption criteria. Table 3 presents that the Kolmogrov-Smirnov test show a asignifincance value of 0.20 that is above 0.05 . As such, the data are normally distributed.

\begin{tabular}{lc}
\multicolumn{2}{c}{ Table 3 Results of Kolmogorov-Smirnov test } \\
\hline Sig. \\
\hline Source: Processed data 2017 & $0.200^{*}$
\end{tabular}

Similarly, the results of multicollinearity test find that no correlation exist between independent variables with VIF value lower than 10 as shown in Table 4 .

Table 4 Results of multicollinearity test

\begin{tabular}{|c|c|c|}
\hline \multicolumn{3}{|l|}{ Coefficientsa } \\
\hline & & VIF \\
\hline & (Constant) & \\
\hline & Debt to Total Assets & 1.688 \\
\hline & Cash Ratio & 1.327 \\
\hline & Firm Size & 1.095 \\
\hline & Return on Assets & 1.434 \\
\hline & Growth & 1.064 \\
\hline
\end{tabular}

Source: Processed data of SPSS 21 of 2017

Table 5 shows the results of the durbin-watson test. Based on the results of regression analysis in Table 5, the calculation value of Durbin Watson is 2.001, while the magnitude of DW-table: dl (outer boundary) is 1.4866; du (internal limit) is 1.7698 ; $4-\mathrm{du}$ is 2,2302; and $4-\mathrm{dl}$ is 2.5134 . As such, the results show that the DW-test lies in the test area.

Table 5. Result Durbin-Watson Test

\begin{tabular}{lc}
\hline \multicolumn{1}{c}{ Model Summary $^{\mathrm{b}}$} \\
\hline \multicolumn{1}{c}{ Durbin-Watson } \\
\hline \multicolumn{1}{c}{2.001} \\
\hline a. Predictors: (Constant), Growth, Return on Assets, Cash Ratio, Firm Size, Debt to \\
Total Assets \\
\hline b. Dependent Variable: Dividend Payout Ratio \\
\hline Source: Processed data of SPSS 21 of 2017
\end{tabular}

These results indicate that DW is located in the test area, which means that the regression model does not contain autocorrelation, so no other test is needed to determine the presence or absence of autocorrelation.

The results of heteroscedasticity test can be seen from Figure 1. Figure 1 presents the data distribution has not formed a pattern that has met the classical assumption of heteroscedasticity free.

\section{Multiple Regression Analysis}

From the data obtained then analyzed by regression method and calculated by using SPSS program. Based on the SPSS output, partially the effect of the six independent variables are debt to total assets, cash ratio, firm size, return on assets and Growth. against Parliament is shown in Table 6. 
Dependent Variable: Dividend Payout Ratio

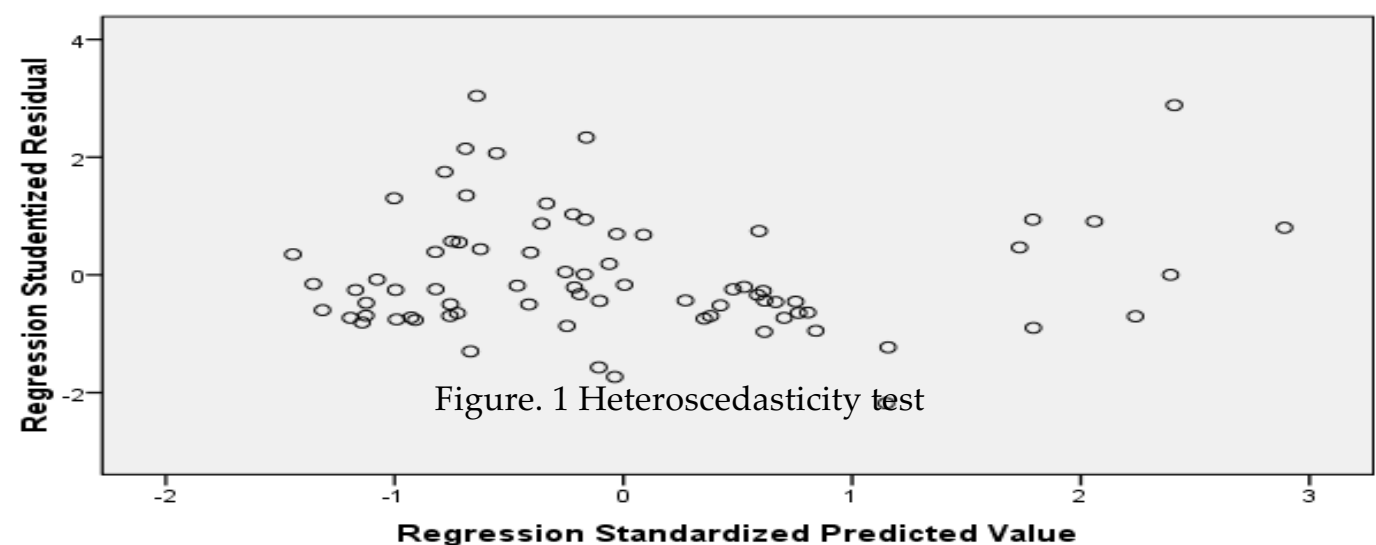

Table 6 Results of multiple regression Analysis

\begin{tabular}{l|l|c}
\hline \multicolumn{2}{c}{ Model } & \multicolumn{2}{c}{ Coefficients $^{\mathrm{a}}$} \\
\cline { 3 - 3 } \multicolumn{2}{c|}{} & Unstandardized Coefficients \\
\hline \multirow{2}{*}{1} & (Constant) & -35.114 \\
\cline { 2 - 3 } & Debt to Total Assets & -0.312 \\
\cline { 2 - 3 } & Cash Ratio & -0.067 \\
\cline { 2 - 3 } & Firm Size & 48.009 \\
\cline { 2 - 3 } & Return on Assets & 1.110 \\
\cline { 2 - 3 } & Growth & 0.003 \\
\hline
\end{tabular}

a. Dependent Variable: Dividend Payout Ratio

Source: Processed data of SPSS 21 of 2017

Based on table 6 then the research equation can be formulated as follows:

$\mathrm{DPR}=-35.114-0.312 \mathrm{DTA}-0.67 \mathrm{X} 2 \mathrm{CR}+48.009$ Firm Size + 1.110ROA + 0.003Growth + $\mathrm{e}$

\section{Hypotheses Testing}

Table 7 F-Test Results

\begin{tabular}{llc}
\hline \multicolumn{1}{c}{ Model } & \multicolumn{1}{c}{ ANOVA $^{\mathbf{b}}$} & Sig. \\
\hline \multirow{2}{*}{1} & Regression & $0.002^{\mathrm{a}}$ \\
\cline { 2 - 3 } & Residual & \\
\cline { 2 - 3 } & Total & \\
\hline
\end{tabular}

a. Predictors: (Constant), Growth, Return on Assets, Cash Ratio, Firm Size, Debt to Total Assets

\section{b. Dependent Variable: Dividend Payout Ratio}

Source: Processed data of SPSS 21 of 2017

The simultaneous testing is done by F-test to test the significance of the influence of all independent variables (debt to total assets, cash ratio, firm size, return on assets, and growth) to the dividend payout ratio on manufacturing companies paying dividends at least 4 years in a row during the study period. Table 7 shows the results that independent variables (debt to totaal assets, cash ratio, firm size, return on assets, and growth) have significance value of 0.002 that is smaller than the level of significance 0.05 . The results of the analysis show that all independent variables have significant effect on dividend payout ratio.

\section{Discussion of Research Results}

Simultaneously, debt to total assets, firm size, and return on assets significantly influence dividend payout ratio. This results supports Chasanah (2008), Puspita (2009) and Handayani (2010). While the 
cash ratio and growth variables are not significant to the dividend payout ratio. This supports the Basuki (2012) and Hidayat (2015).

Table 8 Results of t-test

\begin{tabular}{|c|c|c|c|}
\hline \multicolumn{4}{|c|}{ Coefficients $^{a}$} \\
\hline \multicolumn{2}{|r|}{ Model } & Unstandardized Coefficients & \multirow[t]{2}{*}{ Sig. } \\
\hline \multirow{7}{*}{1} & & & \\
\hline & (Constant) & -35.114 & 0.265 \\
\hline & Debt to Total Assets & -0.312 & 0.035 \\
\hline & Cash Ratio & -0.067 & 0.051 \\
\hline & Firm Size & 48.009 & 0.011 \\
\hline & Return on Assets & 1.110 & 0.000 \\
\hline & Growth & 0.003 & 0.990 \\
\hline
\end{tabular}

a. Dependent Variable: Dividend Payout Ratio

Source: Processed data of SPSS 21 of 2017

The first hypothesis proposed that debt to total assets has a significant effect on dividend payout ratio. The result in Table 8 show that debt to total assets has a negative effect with a regression value of minus 0.312 and a significance value of 0.035 . This means that $\mathrm{H}_{1}$ is supported, that debt to total assets has a negative and significant effect on the dividend payout ratio because the value of significance is smaller than the significance level 0.05 . The results of this study are not in line with Basuki's research which report that debt to total assets has a negative regression coefficient. Whereas, Chasanah (2008) show a positive and insignificant effect of debt to total assets on dividend payout ratio.

The second hypothesis proposed that the cash ratio has a significant effect on dividend payout ratio. In contrast, the results show that cash ratio has no significant effect on dividend payout ratio with a regression value of $-0,067$. The results show a significance value of 0.051 which is greater than the significance level 0.05 . This means $\mathrm{H}_{2}$ is not supported, there is no significant influence between growth against dividend payout ratio.

Cash ratio can be used as an investment indicator for investors because as the cash ratio increases, the dividend payout ratio also increases. The positive sign in the variable cash ratio shows that an increase in the amount of cash in the company will correlate with an increase in the dividend payment. So, the more liquid a company, the higher the dividend payout from the company. The amount of cash earned by the company, has fulfilled its short-term liabilities, so that the company can pay dividend for each period. The results of this analysis are in line with the Puspita (2009) that show cash ratio has a positive and significant effect on dividend payout ratio.

The third hypothesis proposed that firm size has a significant effect on dividend payout ratio. The results show that firm size has a positive effect on dividend payout ratio with a regression value of 48.009 and significance value of 0.011 . This means that firm size has a positive and significant effect on the dividend payout ratio because the significance value is smaller than the significance level 0.05 . The positive direction means that the company is trying to increase its assets through sales that will affect the size of the company. Due to the higher level of sales it is expected an increase in cash inflows so that the dividend payments will be higher as well. The results show that the higher the companies' size, the higher the Dividend Payout Ratio (DPR). The size of the company plays a role in the magnitude of the dividend payout ratio. Large companies tend to have easier access to the capital market, so companies can pay higher dividends than their profits. Thus, reducing their dependence on internal funding. The results of this analysis consistent with Handayani (2010).

The fourth hypothesis proposed that return on assets has a significant effect on the dividend payout ratio. The results show that return on assets have a positive effect with a regression value of 1.110 and a significance value of 0.000 . This means that return on assets has a positive and significant effect on the dividend payout ratio because the value of significance is smaller than the significance 
level 0.05 . The positive direction of the regression coefficient indicates that as ROA increases, the dividend payout ratio also increases. The results show that return on asset explained that the level of profitability of the company and will have an impact on increasing dividend distribution by the company.

The increase in dividend is a signal to investors that management foresees a good income in the future. Companies that have large profits will determine the dividend policy to larger shareholders. According to Hanafi (2004), companies that have a good cash flow or profitability can pay dividend or increase their dividend, and vice versa. Another reason for dividend payments is to avoid acquisitions by other companies. Companies that have excessive cash are often targeted in the acquisition. To avoid acquisitions, a company can pay dividend, and at the same time make the shareholders happy. The results of this analysis in line with Puspita (2009) who describes that ROA has a positive and significant effect on the dividend payout ratio.

The fifth hypothesis proposed that growth has a significant effect on dividend payout ratio. the relust show a regression value of 0.003 and a significance value of 0.990 . This means there is no significant influence between growth has no significant influence on dividend payout ratio. The results show an in significant influence of growth on DPR due to fluctuations in the value of growth, there are companies with low sales growth but has a high ratio of dividend payout ratio. This is due to the consideration that dividends are distributed even though they have the effect of attracting investment, but the dividend distribution can also weaken the financial position of the next period. The results of this study indicate that companies that expect a high rate of sales growth will maintain a low dividend payout ratio to strengthen internal financing. The results of this analysis support the findings of Chasanah (2008) that reported a regression coefficient of -0.277 with a significance value of 0.093 , indicating an insignificant influence of growth on dividend payout ratio.

\section{Determination Coefficient}

Table 9. Results of Determination Coefficient $\left(\mathrm{R}^{2}\right)$

\begin{tabular}{ccccc}
\hline \multicolumn{4}{c}{ Model Summary } \\
\hline Model & $\mathrm{R}$ & $\mathrm{R}$ & $\begin{array}{c}\text { Adjusted } \\
\text { Square }\end{array}$ & $\begin{array}{c}\text { Std. Error of the } \\
\text { Estimate }\end{array}$ \\
\hline 1 & $0.485^{\mathrm{a}}$ & 0.235 & 0.179 & 25.766206 \\
\hline Source: Processed data of 2017 & &
\end{tabular}

Table 9 shows that the determinant coefficient $\left(\mathrm{R}^{2}\right)$ is 0.179 or $17.9 \%$. This shows that $17.9 \%$ Dividend Payout Ratio (DPR) is influenced by variables DTA, CR, ROA, SIZE and Growth. While the rest of $82.1 \%$ is explained by other variables.

\section{Conclusions}

This study aims to examine the influence of five factors (debt to total assets, cash ratio, firm size, return on assets, and growth) on the dividend policy of manufacturing companies listed in the Stock Exchange. The sample of this study was 21 manufacturing companies listed in the Indonesian Stock Exchange (IDX). The type of data used was secondary data in the form of financial statements contained in the Indonesian Capital Market Directory (ICMD). The statistical method used to test the research hypotheses was multiple regression.

Several important results of this study are as follows. First, the debt to total assets (DTA) has a negative and significant effect on the dividend payout ratio. Second, cash ratio has no significant effect on dividend payout ratio. Third, the firm size has a positive and significant effect on the dividend payout ratio. Fourth, return on assets has a positive and significant effect on the dividend payout ratio. Finally, growth has no significant effect on the dividend payout ratio.

Some some suggestions for future studies are as follows. Future studies should expand the sample size to cover the entire population of listed companies in the Indonesian Stock Exchange. The future 
researchers, then, need to extend the observation period, because the longer the observation time interval, the more accurate the forecast for the investment world. Further research should also consider other variables that may affect dividend payout ratios, such as performance, effectiveness, political and security developments, economics, technology, and other variables. The results of this line of research are expected to provide useful information in investment decision making. In addition, investors should also consider external factors such as market conditions that will indirectly affect the companies' profit generating ability in making their investments decisions.

\section{References}

Arilaha, M. A. (2013). Pengaruh free cash flow, profitabilitas, likuiditas, dan leverage terhadap kebijakan deviden. Jurnal Keuangan dan Perbankan, 13(1), 78-87.

Arilaha, M. A. (2013). Pengaruh free cash flow, profitabilitas, likuiditas, dan leverage terhadap kebijakan deviden. Jurnal Keuangan dan Perbankan, 13(1), 78-87.

Bambang, R. (2001). Dasar-dasar pembelanjaan perusahaan. Edisi Keempat, Yogyakarta: BPFE.

Basuki, A. (2012). Analisis pengaruh cash ratio, debt to total assets ratio, debt equity ratio, return on assets, dan net profit margin terhadap dividend payout ratio perusahaan otomotif yang listing di Bursa Efek Indonesia periode 2007-2011. Doctoral dissertation. Fakultas Ekonomika dan Bisnis.

Brigham, E. F., \& Houston, J. F. (2010). Manajemen Keuangan Edisi Kedelapan. Jakarta: Penerbit Erlangga.

Chasanah, A. N. (2008). Faktor-faktor yang mempengaruhi dividend payout ratio (DPR) pada perusahaan yang listed di Bursa Efek Indonesia (Perbandingan pada perusahaan yang sebagian sahamnya dimiliki oleh manajemen dan yang tidak dimiliki oleh manajemen). Doctoral dissertation. Universitas Diponegoro, Semarang.

Ghozali, I. (2012). Statistik Non-Parametrik: Teori dan Aplikasi dengan Program SPSS. Semarang: Universitas Diponegoro.

Hanafi, M. M. (2004). Manajemen keuangan. Yogyakarta: BPFE.

Handayani, D., \& Sofian, S. (2010). Analisis faktor-faktor yang Mempengaruhi dividen payout ratio Pada perusahaan manufaktur di Bursa efek indonesia periode 2005-2007. Doctoral dissertation. Universitas Diponegoro, Semarang.

Hidayat, M. (2015). Pengaruh earning per share dan cash ratio terhadap dividen payout ratio dengan asset growth sebagai variabel moderasi pada sektor industri barang konsumsi di BEI periode 2009-2012. Jurnal Measurement, 9(1), 19-31.

Muktisari, R. (2014). Analisis pengaruh current ratio, debt to equity ratio dan return on asset terhadap devidend payout ratio (DPR) pada perusahaan manufaktur yang terdaftar BEI periode 2010-2012. Doctoral dissertation. Universitas Muhammadiyah Surakarta, Solo.

Praswati, N. A, Syamsudin, Muzakar Isa, T. P. (2016). Strategi pemasaran katalog produk (Studi kasus pengrajin bambu Sukodono Sragen). Benefit Jurnal Manajemen dan Bisnis, 1(2), 149-155.

Puspita, F. (2009). Analisis faktor-faktor yang mempengaruhi kebijakan dividend payout ratio (Studi kasus pada perusahaan yang terdaftar di Bursa Efek Indonesia periode 2005-2007). Doctoral dissertation. Universitas Diponegoro, Semarang. 